\title{
Taxonomy and nomenclature of some members within the Obtusae section of Nitzschia Hassall (Bacillariophyceae) including descriptions of two new species
}

\author{
Sarah E. HAmsher ${ }^{1 *}$, J. Patrick KocioleK ${ }^{2}$, Sarah A. Spaulding ${ }^{3} \&$ Amal I. SALEH ${ }^{4}$
}

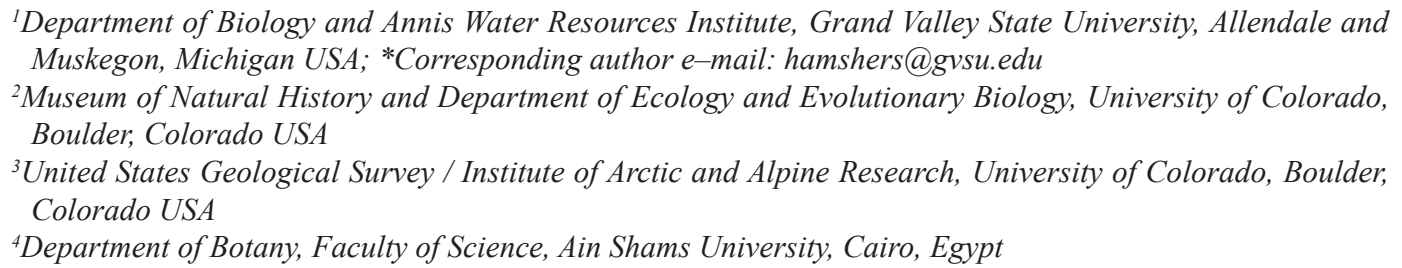

\begin{abstract}
Light and scanning electron microscope observations are made on some members of the section Obtusae in the genus Nitzschia (Bacillariales, Bacillariophyceae). We use type and other material derived from both the National Water Quality Assessment (NAWQA) program in the USA and from Egypt to assess five different taxa, two of which are described as new to science (Nitzschia lowei, sp. nov., Nitzschia potapovae, sp. nov.) and another is made as a new nomenclatural combination (Nitzschia kurzeana var. multistriata (Hohn) comb. nov.). Other names used in the literature for some of these taxa are considered and discussed. Based on the features of sigmoid valves, eccentric raphe not in an elevated keel, lack of a conopeum, strongly bent, elongated external proximal raphe ends extending onto the valve face, and presence of a differentiated central 'nodule', members of this group are clearly differentiated from the generitype of Nitzschia and most other recognized sections of the genus.
\end{abstract}

Key words: light microscopy, new species, new combination, Nitzschia, nomenclature, scanning electron microscopy, Section Obtusae, taxonomy

\section{INTRODUCTION}

The genus Nitzschia, with nearly 3,000 named taxa (KocioleK et al. 2020a), is one of the largest genera of diatoms. Like many large genera, Nitzschia has been divided into a number of sections, whose designations and diagnoses go back 140 years to the work of CLEVE $\&$ GRUNOW (1880). These sections are recognized by the shape of the valves (e.g., the 'Sigmoideae', which also bears the generitype of the genus Nitzschia; the Lanceolatae, which accounts for many of the taxa in the genus; Nitzschiella with attenuated and curved ends), organization and structure of the fibulae (Epithemoideae), position of the raphe system (Dissipatae), among others (see Cleve \& Grunow 1880; Mann 1978; Krammer \& LANGe-Bertalot 1988). Some of the sections have been recognized as distinct genera, such as Tryblionella (W. Sмith 1853; Mann in Round et al. 1990; Rimet et al. 2011; Bertolli et al. 2019), Grunowia (RABENHORST 1864; AbOAL et al. 2003; KocioleK et al. 2020b), and Psammodictyon (Mann in Round et al. 1990; YANG et al. 2020), but most have remained within Nitzschia.
Since the generitype of Nitzschia is in a group called 'Sigmoideae', this group is Nitzschia sensu stricto and that is how we will reference it herein. Phylogenetic analyses have shown that the genus Nitzschia is not monophyletic (Rimet et al. 2011; Kim et al. 2019; ManN et al. 2021), and although taxon sampling among many of the sections is sparse, the morphological differences of some sections show them to be monophyletic and support classification distinct from Nitzschia (e.g., RIMET et al. 2011; KIM et al. 2019).

One of the smaller sections within Nitzschia is the Obtusae section. The Obtusae section shares the feature of having sigmoid valves with Nitzschia sensu stricto, but differences from Nitzschia sensu stricto include: Obtusae members lack a conopeum, have distinctive external proximal raphe ends (strongly deflected and elongated), and the structure and position of the raphe differs (not positioned in a keel, and placed on the mantle of the valve; e.g., Cleve \& Grunow 1880; KRAMmer \& LANGE-Bertalot 1988; MetZeltin et al. 2005).

When he proposed the Obtusae section, Grunow (in Cleve \& Grunow 1880) included seven taxa, including 
its namesake, $N$. obtusa. Krammer \& LANGE-BertaLOT (1988) included fourteen taxa in the section (Table 1). Together, there are a total of eighteen taxa considered part of the Section Obtusae in these references. Although there are relatively few species in the section, some of these species contain a number of varieties; many of these taxa have taxonomic and nomenclatural issues. For example, "N. obtusa var. kurzii Rabenhorst ex Cleve et Moller" (VANLANDingham 1978; FourTANIER \& KocIOLEK 2011) is the name given to a brackish to marine diatom species that appears in a common reference guide for diatom taxonomy (KRAMMER \& LANGE-BerTALOT 1988), but that taxon name has not been validly published. Due to its inclusion in KrAMMER \& LANGE-Bertalot (1988), $N$. obtusa var. kurzii has been frequently applied to specimens in the United States Geological Survey National Water Quality Assessment (NAWQA) program data set. This diatom has many nomenclatural designations, and the distinctions between taxa in this species group, and across taxa in the Obtusae section as a whole, are not easily recognized.
The purpose of this study is to investigate and resolve the taxonomy and nomenclature of "Nitzschia obtusa var. kurzii" and some other large sigmoid taxa in the Obtusae section of Nitzschia. We examined type material of Nitzschia kurzeana Rabenhorst, Nitzschia obtusa W. Smith and Nitzschia obtusa var. multistriata Hohn. We also examined specimens identified as these taxa from North America (as part of NAWQA) and other locations from outside of North America to compare them with the type material. Based on these observations, we clarify the identity of some of the taxa in this section, propose two new species, propose a new nomenclatural combination, and discuss the systematic position of the Obtusae section relative to other sections within Nitzschia.

\section{Materials AND Methods}

Observations in this study are based on prepared slides and material obtained primarily from the Academy of Natural Sciences of Drexel University (ANS), including the: Cleve \& Möller

Table 1. Taxa identified as belonging to the subgroup Obtusae of Nitzschia in Cleve \& Grunow (1880) and Krammer \& Lange-Bertalot (1988).

\begin{tabular}{|c|c|c|}
\hline Taxon & Author & Reference(s) \\
\hline Nitzschia amplectens & Hustedt & $\begin{array}{l}\text { HUSTEDT 1957; SiMONSEN 1987; KRAMMER \& LANGE- } \\
\text { BERTALOT } 1988\end{array}$ \\
\hline N. brevissima & Grunow & KRAMMER \& LANGE-BERTALOT 1988 \\
\hline N. clausii & Hantzsch & HANTZSCH 1860; KRAMMER \& LANGE-BERTALOT 1988 \\
\hline N. filiformis & (W. Smith) Van Heurck & $\begin{array}{l}\text { VAN HEURCK 1896; Krammer \& LANGE-BERTALOT } \\
1988\end{array}$ \\
\hline N. filiformis var. conferta & (Richter) Lange-Bertalot & RiCHTER 1879; KRAMMER \& LANGE-BERTALOT 1988 \\
\hline N. improvisa & Simonsen & SimONSEN 1960; KRAMMER \& LANGE-BERTALOT 1988 \\
\hline N. kurzii & Rabenhorst ex Cleve et Grunow & Cleve \& Grunow 1880 \\
\hline N. nana & Grunow & $\begin{array}{l}\text { VAN HEURCK 1880; KRAMMER \& LANGE-BERTALOT } \\
1988\end{array}$ \\
\hline N. obtusa & W. Smith & $\begin{array}{l}\text { SMith 1853; CleVE \& GRUNOW 1880; KRAMMER \& } \\
\text { LANGE-BERTALOT } 1988\end{array}$ \\
\hline N. obtusa var. maxima* & Grunow & Cleve \& Grunow 1880 \\
\hline N. obtusa var. vulgaris & Grunow & Cleve \& Grunow 1880 \\
\hline N. obtusa var. schweinfurthii & (Grunow) Grunow & $\begin{array}{l}\text { Cleve \& GRUNOW 1880; Krammer \& LANGE-BerTA- } \\
\text { LOT } 1988\end{array}$ \\
\hline N. obtusa var. lepidula & Grunow & Cleve \& Grunow 1880 \\
\hline N. prolongata & Hustedt & $\begin{array}{l}\text { HuSTEDT 1938; SiMONSEN 1987; KRAMMER \& LANGE- } \\
\text { BERTALOT } 1988\end{array}$ \\
\hline N. prolongata var. hoehnkii & (Hustedt) Lange-Bertalot & $\begin{array}{l}\text { HuSTEDT 1959; SiMONSEN 1987; KRAMMER \& LANGE- } \\
\text { BERTALOT } 1988\end{array}$ \\
\hline N. scalpelliformis** & Grunow & $\begin{array}{l}\text { Cleve \& GRunOW 1880; KRAMMER \& LANGE-BERTA- } \\
\text { LOT } 1988\end{array}$ \\
\hline N. subcohaerens var. scotica & (Grunow) Van Heurck & $\begin{array}{l}\text { VAN HEURCK 1880; KRAMMER \& LANGE-BERTALOT } \\
1988\end{array}$ \\
\hline N. terrestris & (Petersen) Hustedt & Petersen 1928; Krammer \& LANGe-Bertalot 1988 \\
\hline
\end{tabular}

*Considered part of $N$. obtusa var. schweinfurthii by Krammer \& LANGE-BerTalot (1988)

**Considered as N. obtusa var. scapelliformis by CLEVE \& GRUNOw (1880). 
Collection, Rabenhorst Exsiccatae, H.L. Smith Collection, W. Smith Collection, and the General Collection. Type material from the W. Smith Collection for the SEM observations was generously provided by the Natural History Museum (BM). Additional samples collected from Egypt (Table 2) were oxidized according to PATrick \& Reimer (1966, p. 94) without potassium dichromate, using sodium nitrate instead of it. Cleaned material was mounted using Naphrax (Brunel Microscopes Ltd., Chippenham, UK). Materials from the USGS NAWQA program were processed using NAWQA protocols (CHARLES et al. 2002). These materials are listed in Table 3. Finally, we examined the type material of Nitzschia obtusa var. multistriata Hohn in PATRICK et al. (1966) on ANSP GC slide 25861a.

Light micrographs (LM) were obtained using a Leica DMLB2 (1.4 NA 100×), a Zeiss Axioscope (1.3 NA 100×), or a Serico microscope equipped with digital imaging systems. For scanning electron micrographs (SEMs), material was dried on aluminum stubs, coated with gold/palladium, and studied using a Zeiss Supra 50VP SEM at $10 \mathrm{kV}$ at Drexel University.

\section{RESULTS}

Nitzschia obtusa W. Smith (Figs 1-10)

Sмітн 1853, p. 39, plate 13: 109.

Isotype Material: W. Smith 109.

Slide examined: W. Smith 109 (ANSP 78)

Location: Shagalieu Marsh, Poole Bay, 1849

Collector: W. Smith

Original description: "F. of F.V. linear, with rounded extremities; V. linear, obtuse; puncta double; striae 56 in .001 ". Length .0042" to .0121". v.v." The measurements made by Smith are in English inches, and we convert them here to microns: Striae are 22 in $10 \mu \mathrm{m}$. Length 106-307 $\mu \mathrm{m}$.

LM observations: Twenty-five specimens were observed and measured. Frustules with nitzschioid symmetry (Figs $1-5$ ). In valve view, valves are sigmoid linear and elongate with rounded to slightly cuneate apices, 221-300 $\mu \mathrm{m}$ long and 8.5-11.4 $\mu \mathrm{m}$ wide. Striae are not resolvable in the slides examined due to the thickness of the coverslip. Canal raphe is eccentric and interrupted at the center. No obvious keel is present. Marginal fibulae number $4-6$ in $10 \mu \mathrm{m}$.

SEM observations: Externally (Figs 7-8) the canal raphe is eccentric between the valve and the mantle with proximal raphe ends strongly bent and extended onto the valve face and distal raphe ends hooked at the apex and extending onto the valve mantle on the valve examined. Striae are parallel at the center, and convergent at the apices and composed of round to elliptical areolae. The more elliptical areolae appear two rows from the raphe and areolae appear unoccluded externally.

Internally (Figs 6, 9, 10), the marginal raphe system is subtended by fibulae that widen towards the valve face to form round to elliptically shaped portulae. Fibulae have 3-4 small ribs that fuse in the center and bridge the raphe canal. Fibulae vary in width and density. Areolae have hymenate occlusions internally. At the central nodule, internal proximal raphe ends appear as a double helictoglossa (Fig. 9, arrow). Distal raphe ends terminate in helictoglossae at the distal ends prior to the external terminal fissure.

Remarks: One discrepancy between Smith's original description and our own observations was the stria density. Smith reports 22 striae in $10 \mu \mathrm{m}$, but our observations in the SEM (striae were not resolvable in LM) indicate a stria density $>40$ in $10 \mu \mathrm{m}$. Striae are also not visible in Smith's drawings of this taxon either. Further examination of all of Smith's collections of N. obtusa would be necessary to resolve this discrepancy.

\section{Nitzschia lowei sp. nov. (Figs 11-16)}

Description: Valves elongate, with apiculate ends. Valve outline nearly symmetrical in relation to apical axis. Length 119.6 to $182.8 \mu \mathrm{m}$, breadth 6.6-9.8 $\mu \mathrm{m}$. Fibulae 5-7 in $10 \mu \mathrm{m}$. Striae not resolvable.

Holotype: Cleve \& Möller \#77, Academy of Natural

Table 2. Location information for specimens collected from Egypt.

\begin{tabular}{|c|c|c|c|c|c|c|c|}
\hline Locality & $\begin{array}{l}\text { Latitude, } \\
\text { Longitude }\end{array}$ & Habitat & Frequency & Salinity & Collector & $\begin{array}{l}\text { Date of col- } \\
\text { lection }\end{array}$ & Figure(s) \\
\hline $\begin{array}{l}\text { El Minia Governorate, } \\
\text { Maghagha, El-Yateem drain- } \\
\text { age Canal }\end{array}$ & $\begin{array}{l}28^{\circ} 38^{\prime} 54^{\prime \prime} \mathrm{N} \\
30^{\circ} 50^{\prime} 32^{\prime \prime} \mathrm{E}\end{array}$ & scum & predominant & $\begin{array}{l}\text { Slightly } \\
\text { brackish }\end{array}$ & $\begin{array}{l}\text { Amal I. } \\
\text { Saleh }\end{array}$ & $\begin{array}{l}24-J u l- \\
2019\end{array}$ & 69 \\
\hline $\begin{array}{l}\text { Giza Governorate, Abo El- } \\
\text { Nomros irrigation Canal }\end{array}$ & $\begin{array}{l}29^{\circ} 57^{\prime} 04^{\prime \prime} \mathrm{N} \\
31^{\circ} 12^{\prime} 17^{\prime \prime} \mathrm{E}\end{array}$ & Epilithic & predominant & $\begin{array}{l}\text { Fresh } \\
\text { water }\end{array}$ & $\begin{array}{l}\text { Amal I. } \\
\text { Saleh }\end{array}$ & $\begin{array}{l}\text { 14-Nov- } \\
2019\end{array}$ & 68 \\
\hline $\begin{array}{l}\text { Giza Governorate, Abo El- } \\
\text { Nomros irrigation Canal }\end{array}$ & $\begin{array}{l}29^{\circ} 57^{\prime} 04^{\prime \prime} \mathrm{N} \\
31^{\circ} 12^{\prime} 17^{\prime \prime} \mathrm{E}\end{array}$ & $\begin{array}{l}\text { Phyto- } \\
\text { plankton }\end{array}$ & rare & $\begin{array}{l}\text { Fresh } \\
\text { water }\end{array}$ & $\begin{array}{l}\text { Amal I. } \\
\text { Saleh }\end{array}$ & $\begin{array}{l}14-\mathrm{Nov}- \\
2019\end{array}$ & 67 \\
\hline $\begin{array}{l}\text { Giza Governorate, Abo El- } \\
\text { Nomros irrigation Canal }\end{array}$ & $\begin{array}{l}29^{\circ} 57^{\prime} 04^{\prime \prime} \mathrm{N} \\
31^{\circ} 12^{\prime} 17^{\prime \prime} \mathrm{E}\end{array}$ & scum & predominant & $\begin{array}{l}\text { Fresh } \\
\text { water }\end{array}$ & $\begin{array}{l}\text { Amal I. } \\
\text { Saleh }\end{array}$ & $\begin{array}{l}14-\mathrm{Nov}- \\
2019\end{array}$ & 64,66 \\
\hline $\begin{array}{l}\text { El-Fayum Governorate Lake } \\
\text { Qarun }\end{array}$ & $\begin{array}{l}29^{\circ} 27^{\prime} 56^{\prime \prime} \mathrm{N} \\
30^{\circ} 33^{\prime} 48^{\prime \prime} \mathrm{E}\end{array}$ & scum & rare & Saline & $\begin{array}{l}\text { Amal I. } \\
\text { Saleh }\end{array}$ & $\begin{array}{l}14-\text { Aug- } \\
2014\end{array}$ & 65 \\
\hline
\end{tabular}


Sciences of Drexel University

Type locality: Villerville, Normandie, [France] collected by A. de Brébisson.

Etymology: Dedicated to Dr. Rex Lowe, for his many contributions to diatom research, throughout his career and during his retirement.

Remarks: Cleve \& Möller identified this taxon as $N$. obtusa, but it displays differences in valve outline ( $N$. lowei is more linear and less sigmoid) and length ( $N$. lowe i is smaller). In general, specimens of $N$. lowei, are more narrow and have more fibulae in $10 \mu \mathrm{m}$. The size range of $N$. lowei and $N$. obtusa overlap.

\section{Nitzschia potapovae sp. nov. (Figs 17-26) Description}

LM Observations: Ten specimens were observed and measured. Frustules with nitzschioid symmetry (Figs 17-21). In valve view, valves sigmoid, linear; and elongate with bluntly rounded apices, 182-346 $\mu \mathrm{m}$ long and 7-10 $\mu \mathrm{m}$ wide. Striae number $20-22$ in $10 \mu \mathrm{m}$. Canal raphe is eccentric and interrupted at the center. No obvious keel present. Marginal fibulae 5-6 in $10 \mu \mathrm{m}$.

SEM Observations: Externally in the SEM (Figs 22, $23,25)$ the canal raphe is eccentric between the valve and the mantle with proximal raphe ends strongly bent and extended onto the valve face (Fig. 23) and distal raphe ends hooked at the apex and extend onto the valve mantle on the valve we observed (Fig. 25). Striae are composed of round areolae that are parallel at the center, and slightly convergent at the apices. Enlarged areolae appear two rows from the raphe. Areolae on the mantle opposite the external proximal raphe ends are interrupted into a U-shaped pattern (Fig. 23). Areolae appear unoccluded externally. The valvocopulae have a single row of simple poroids (Figs 23, 25).

Internally (Figs 24, 26), the marginal raphe system is subtended by fibulae that widen slightly towards the valve face. Canal raphe is largely open to the valve interior without obvious portulae. Fibulae have $2-4$ small ribs that fuse in the center and bridge the raphe canal. Fibulae vary in width and density. Areolae are not occluded internally. At the central nodule, internal proximal raphe ends appear as small helictoglossae (Fig. 24). Raphe terminate as small helictoglossae at the distal ends prior to the external terminal fissure (Fig. 26).

\section{Holotype: ANSP GC 104804a}

Type Locality: Bayou Castine, Louisiana, USA; (NAWQA GSN 01107).

Etymology: Dedicated to Dr. Marina Potapova, Curator of the Diatom Collection of the Academy of Natural Sciences, Philadelphia, for her help and support in this project and in recognition of her many contributions to diatom research.

Remarks: Specimens on this slide were identified as $N$. obtusa in NAWQA counts, but display differences in the shape of their apices, their proximal raphe ends, and the lack of internal occlusions in the areolae (of $N$. potapovae).

Nitzschia kurzeana Rabenhorst (Figs 27-37)

Isotype Material: Rabenhorst 1873 Exsiccatae Number 2312 Slide examined: ANSP GC \# 35149

Location: Calcutta [India]

Collector: Wilhelm Sulpiz Kurz

Original description: "N. magna, leviter sigmoidea, utroque polo obtusa, nodulis lateralibus magnis. 1 in $0,0001 \mathrm{~m}$. m; valvis late linearibus, ad polos rotundato subcapitatos cuneatis, striis transversalibus subtilissimis." Our translation of the original description into English is as follows: "a large Nitzschia slightly sigmoid, obtuse at either pole, with a distinct central nodule. $100 \mu \mathrm{m}$ long. Valve broadly linear with rounded, subcapitate, cuneate apices, transverse striae very fine."

LM observations on isotype material: Twenty-two specimens were observed and measured. Frustules with nitzschioid symmetry (Figs 27-32). In valve view, valves are slightly sigmoid, linear elongate with cuneate apices curved to opposite sides, 66.7-95.2 $\mu \mathrm{m}$ long, 6.8-8.5 $\mu \mathrm{m}$ wide. Striae are difficult to resolve because of an apparent degradation of the mounting medium. Canal raphe is eccentric and interrupted at the center. No obvious keel is present. Marginal fibulae number $6.5-8.0$ in $10 \mu \mathrm{m}$. SEM observations: Externally, the raphe is eccentric,

Table 3. Location information for specimens collected by NAWQA in the USA.

\begin{tabular}{|c|c|c|c|c|c|c|}
\hline Locality & $\begin{array}{l}\text { Latitude, Lon- } \\
\text { gitude }\end{array}$ & $\begin{array}{l}\text { ANS Sample } \\
\text { Code }\end{array}$ & USGS Sample Code & USGS Site Code & $\begin{array}{l}\text { Date of col- } \\
\text { lection }\end{array}$ & Figures \\
\hline $\begin{array}{l}\text { Tamiami Canal at Bridge, } \\
\text { FL } 030064\end{array}$ & $\begin{array}{l}25^{\circ} 56^{\prime} 15^{\prime \prime} \mathrm{N} \\
81^{\circ} 27^{\prime} 35.99^{\prime \prime} \mathrm{W}\end{array}$ & GS027353 & SOFL0697ARE0012B & 255615081273600 & 18-Jun-97 & $43-52$ \\
\hline $\begin{array}{l}\text { Hillsboro Canal at S-6 } \\
\text { near Shawano, FL }\end{array}$ & $\begin{array}{l}26^{\circ} 28^{\prime} 19.92^{\prime \prime N} \\
80^{\circ} 26^{\prime} 44.88^{\prime \prime} \mathrm{W}\end{array}$ & GS027503 & SOFL0798ARE0010 & 02281200 & 21-Jul-98 & $38-42$ \\
\hline $\begin{array}{l}\text { Bayou Castine at Hwy } \\
190 \mathrm{nr} \text { Mandeville, LA }\end{array}$ & $\begin{array}{l}30^{\circ} 21^{\prime} 5.04 " \mathrm{~N} \\
90^{\circ} 2{ }^{\prime} 21.119^{\prime \prime} \mathrm{W}\end{array}$ & GSN01107 & ACAD1298ARE0008B & 302105090022100 & 08-Dec-98 & $17-26$ \\
\hline $\begin{array}{l}\text { Salado Ck at Loop } 13 \text { at } \\
\text { San Antonio, TX }\end{array}$ & $\begin{array}{l}29^{\circ} 21^{\prime} 24.84^{\prime \prime} \mathrm{N}, \\
98^{\circ} 24^{\prime} 44.999^{\prime \prime} \mathrm{W}\end{array}$ & GSN97121 & SCTX0802ARE0004BC & 08178800 & 14-Aug-02 & $53-57$ \\
\hline
\end{tabular}



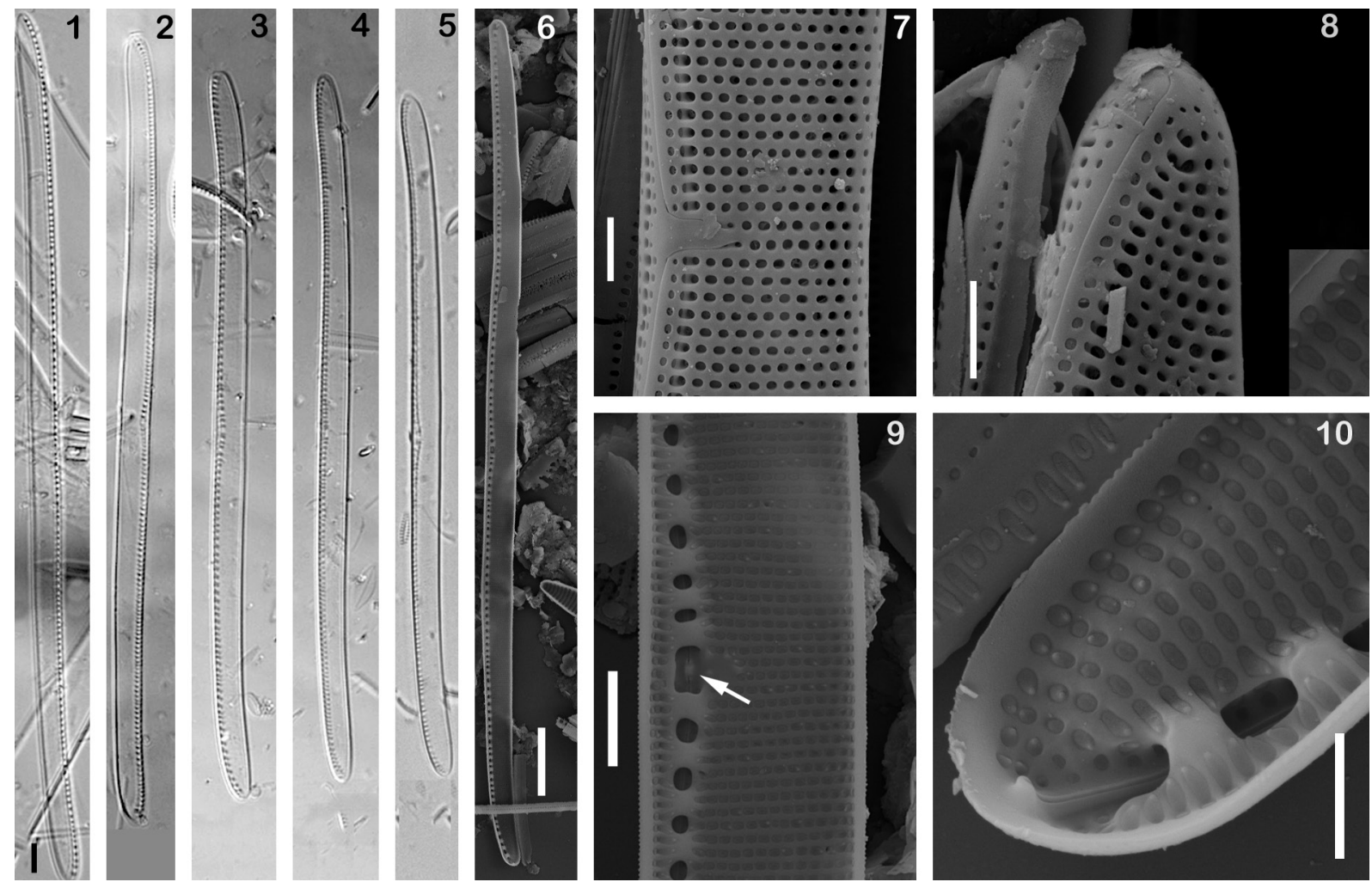

Figs 1-10. Nitzschia obtusa Wm. Smith, LM observations based on isotype slide (Smith 109 / ANSP 78) at the Academy of Natural Sciences, Philadelphia and SEM observations on type specimens based on material at The Natural History Museum, London (Smith 109): (1-5) LM, showing size range; (6-10) SEM: (6) entire valve, interior. Fibulae are evident. (7) valve exterior at the central portion of the valve. External proximal raphe ends are sharply deflected on the valve face. Raphe is eccentric. (8) external view of valve apex. Distal raphe end curves onto the valve face and then onto the mantle at the apex. (9) internal valve view at the central area. Fibulae are broad, forming small portules over canal raphe. Proximal raphe ends are similar to small helictoglossae (arrow). (10) internal view at the valve terminus. Areolae are covered by hymenate occlusions. Fibulae are broad, with occlusions extending onto each fibula. The distal raphe terminates in an helictoglossa positioned on the valve mantle. Scale bars $10 \mu \mathrm{m}(1-6), 1 \mu \mathrm{m}(7-8,10), 2 \mu \mathrm{m}(9)$.

located primarily on the mantle, and curves onto the valve face at the apices (Figs 34, 36). The external distal raphe ends are hooked onto the valve face on the valve we observed (Fig. 36) and the proximal raphe ends are bent and extend onto the valve face (Fig. 34). Striae are radiate, and number $43-50$ in $10 \mu \mathrm{m}$. The valve exterior has two rows of areolae that border the axial area of the raphe on both sides: the first row next to the raphe has very small, round openings and the second row has larger, elongate openings, appearing as exclamation points on opposite sides of the raphe (Figs. 34, 36).

Internally (Figs 33, 35, 37), the marginal canal raphe is subtended by fibulae that are comprised of a fusion of 3-6 ribs from the valve face, forming a thickened bridge over the canal raphe. Fibulae vary in width and density and are only slightly widened towards the valve face. Canal raphe is largely open to the valve interior without obvious portulae. The distal raphe ends terminate in helictoglossae prior to the external terminal fissure (Fig. 37). Internal proximal raphe ends terminate but are not formed into helictoglossa-like structures (Fig. 35). Areolae possess occlusions internally.

\section{Additional collections of $N$. kurzeana}

Collections from North America that correspond to the original description of $N$. kurzeana include samples from: Hillsboro Canal, Southern Florida (Figs 38-42; ANSP GC103574a / NAWQA Sample GS027503); Tamiami Canal, Florida (Figs 43-52; ANSP GC 103254b / NAWQA GS027353); and Salado Creek, Texas (Figs 53-57; ANSP GC 106141a / NAWQA GSN97121). In these populations, the valve margin is linear and elongate, with sigmoid symmetry in relation to apical axis and the central margin of valve is slightly constricted (narrower) than the remainder of the valve. Length ranges from $81-191 \mu \mathrm{m}$, breadth ranges from 6.5 to $9.1 \mu \mathrm{m}$. Fibulae number 5-8 in $10 \mu \mathrm{m}$.

The Tamiami Canal (FL) specimens viewed with SEM show the valve exterior with the raphe positioned on the mantle and proximal raphe ends deflected onto the valve face (Fig. 49). The apex shows the raphe on the mantle with a slight deflection onto the face on the valve we observed (Fig. 50). Internally (Figs 51, 52) the fibulae are shown to have 4-5 smaller ribs connected to a wider fibula. In the valve center a small central nodule separates the proximal raphe ends (Fig. 51). At the apex, the raphe terminates in a small helictoglossa (Fig. 52). Additional observations of this taxon were made from material collected by Kurz in Thaca Choung, East Indies (Figs 58-63; Cleve \& Möller 78) and material collected 
from Egypt (Figs 64-69). The mounting medium on the Cleve \& Möller 78 slide was degraded, which resulted in an abnormal appearance of the fibulae, and the striae were not resolvable. Specimens from the Egyptian populations ranged in length from 60.0-162.6 $\mu \mathrm{m}$ and breadth of 7.5-8.75 $\mu \mathrm{m}$, with $6-8$ fibulae in $10 \mu \mathrm{m}$, well within the range of the populations found in North America and similar in outline. This species may have been recorded previously from Egypt (e.g., FoGED 1980), but the images do not allow positive confirmation of this species. Based on the International Code of Nomenclature for algae, fungi and plants (TuRLAND et al. 2018), the name N. kurzeana Rabenhorst 1873 is validly published and has priority over $N$. kurzii Rabenhorst ex Cleve et Möller and N. kurzii Rabenhorst in Cleve et Grunow. KocIOLEK (2004) notes that the name Nitzschia kurzeana is not included in VANLANDINGHAM's (1978) catalog, and that reference is made to " $N$. kurzii Rabenhorst ex Cleve et Möller \#78”. De Toni (1892, p. 534) lists the name "Nitzschia kurzii Rabenh. in Cl. et. Gr. Arct. Diat. P. 92", and that specimens can be found in CLEVE \& MöLler (1878) and H.L. Smith \#351 (1874). Peragallo (1903, vol. II, p. 664) lists the name for this taxon as " $N$. kurtzii Rabenhorst" and suggests it is the same as what is presented by GRUNOw (1880).

Nitzschia obtusa var. multistriata Hohn (Figs 70-74)

PATrick et al. 1966, p. 489, plate 2, fig. 7.

Type Material: ANSP 25861a

Slide examined: ANSP 25861a

Location: Rio Amazonas, Peru, South America

Collector: M. Hohn

Original description: "Valve broadly linear, ends tapering, rounded, slightly sigmoid. Length $93.4 \mu$; width $8.4 \mu$. Striae fine, parallel, becoming obliquely radiate at ends, $30 / 10 \mu$, indistinctly punctuate. Keel marginal, indented at center. Keel puncta heavy, rectangular, $8 / 10 \mu$, interrupted at center. This variety differs from Nitzschia obtusa W. Sm. in striae count. N. obtusa was originally described (Syn. British Diat. 1, p. 39, pl. 13, fig. 109,1853 ) as having 56 striae in .001" or 20-22 in $10 \mu \mathrm{m}$. This is also shown on the William Smith Type Slide No. 78."

LM observations: Valves range from 84 to $105 \mu \mathrm{m}$ in length and 6 to $10 \mu \mathrm{m}$ in width. Fibulae number 6 to 9 in $10 \mu \mathrm{m}$. Striae were not resolvable in the slide examined.

The shape and proportions of the type population of this taxon suggest it is more closely related to $N$. kurzeana than N. obtusa. The habitat from which this taxon is reported, and the apparently significantly lower stria density reported by Hohn as compared to the type specimens of $N$. kurzeana, suggest at the present it should be maintained as a separate taxon. Hohn's use of the word "keel" probably was meant to refer to the fibulae along the raphe canal. Our observations showed striae finer than 30 in $10 \mu \mathrm{m}$, and since there was no circled specimens on the type slide, we cannot be sure we saw

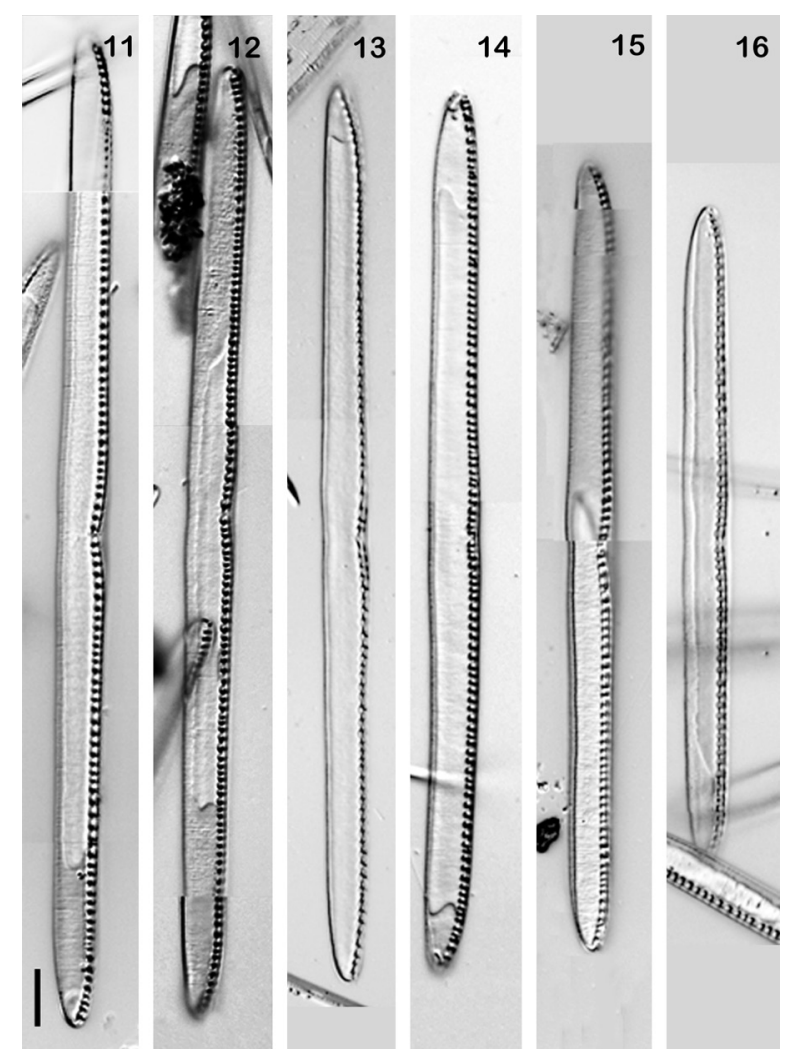

Figs 11-16. Nitzschia lowei, sp. nov., LM, observations made from holotype slide Cleve \& Möller \#77 (Villerville, Normandie) at the Academy of Natural Sciences, Philadelphia. Size range shown. Scale bar $10 \mu \mathrm{m}$.

the exact specimen described by Hohn. We hereby recognize it to be more closely related to, but separate from, the nominate variety of $N$. kurzeana, with its transfer to this species group:

Nitzschia kurzeana var. multistriata (Hohn) comb. nov. Basionym: Nitzschia obtusa var. multistriata Hohn in PATRICK et al. (1966). Bacillariophyta. The Catherwood Foundation Peruvian-Amazon Expedition. XVII. Monographs of the Academy of Natural Sciences of Philadelphia, Vol. 14, p. 489, plate 2, figure 7.

\section{Other names and their nomenclatural status} Nitzschia obtusa var. kurziana Rabenhorst, No. 2353 This taxon is invalid, because it lacks a description. The species was listed from salt lakes in Calcutta, India, from a sample separate from the one used to describe N. kurzeana. The analysis was provided by Grunow within the Rabenhorst exsiccatae and, unlike other diatoms in this sample described as new by Grunow (e.g., Navicula fenzlii Grunow), there is no indication this was proposed as a new taxon. The close spellings of the specific epithet (kurzeana) and variety (kurziana) lead us to believe that an orthographic error accounts for the difference in spelling. However, because the names are of different rank (species and variety) and by the same author (Rabenhorst), we cannot confirm that Rabenhorst made such an error. The name is not included in the lists of in De Toni (1892) or VanLandingham (1978). 

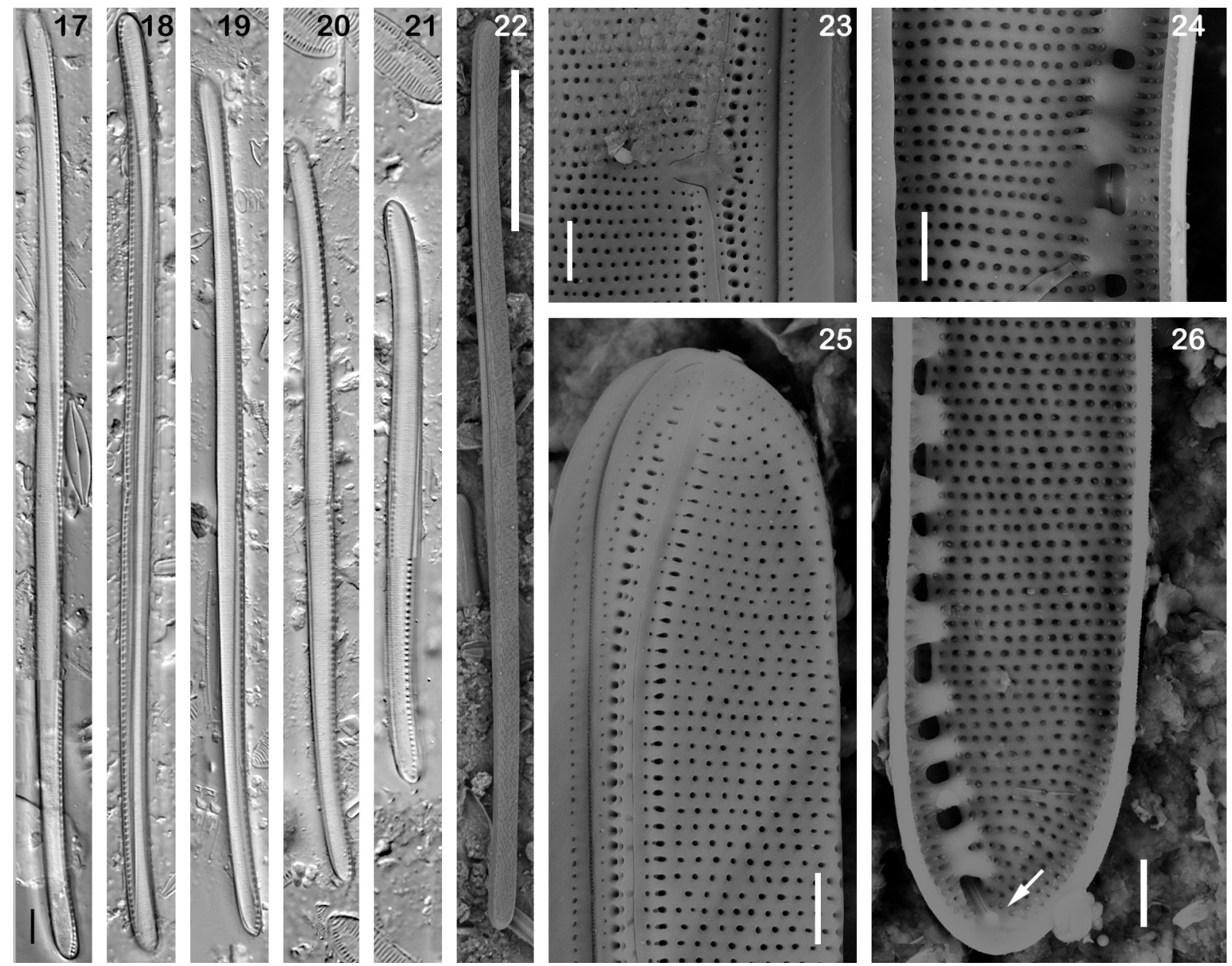

Figs 17-26. Nitzschia potapovae, sp. nov., LM and SEM, observations made from slide GC 104804a (holotype) and type material (NAWQA GSN 01107) from Bayou Castine, Louisiana at the Academy of Natural Sciences, Philadelphia: (17-21) LM showing size range; (22-26) SEM: (22) valve exterior, entire valve, (23) external view of central portion of valve, showing proximal raphe ends deflected onto the valve face, (24) internal view of central area with robust fibulae and small central nodule with proximal raphe ends, (25) external view of one valve end with raphe eccentric, (26) apex of the valve, internal view, with broad fibulae evident. Raphe terminates in small helictoglossa (arrow) positioned on the valve mantle. Scale bars $10 \mu \mathrm{m}(17-21), 50 \mu \mathrm{m}(22), 2 \mu \mathrm{m}(23-26)$.

\section{Nitzschia obtusa var. kurzii Rabenhorst ex Cleve et Möller, No. 78}

This taxon is invalid, because it lacks a description as a variety of the species, $N$. obtusa. It appears in VANLANDINGHAm (1978) as a species, but not as a variety. We are unable to determine if the Cleve \& Moller slides are intended as the type of this taxon.

\section{Nitzschia kurzii Rabenhorst ex Cleve et Möller}

This taxon is invalid, because it lacks a description. It appears in VANLANDINGHAM (1978). We are unable to determine if the Cleve \& Möller slides are intended as the type of this taxon.

\section{Nitzschia kurzii Rabenhorst in Grunow, p. 92}

Type specimen: None designated or illustrated.

Type illustration: None presented.

Description: (translated from the German) "Closely related to N. obtusa, valves linear, slightly bent with wedge shaped and crooked (not straight/bent) ends. Sometimes in the middle slightly thinner (also found in N. obtusa).
Fibulae approximately 7 in $10 \mu \mathrm{m}$. Striae $30-32$ in 10 $\mu \mathrm{m}$. Length 100-140 $\mu \mathrm{m}$, width $9 \mu \mathrm{m}$. Bengal, very common in slightly salty water."

Remarks: This taxon is valid according to Silva (INDEX Nominum Algarum 1997-2009). VAnLandingham (1978) lists this taxon as an alternate to N. kurzeana, implying that VanLandingham considered it a synonym. The species was described from Bengal. Both N. kurzeana and $N$. kurzii are described from the Indian subcontinent and it would be reasonable to compare these two taxa to determine if they are, indeed, distinct species. Although N. kurzeana and N. kurzii have completely distinct, non-overlapping size ranges (in their original descriptions), it seems possible that they are part of the same size diminution series. When comparing Nitzschia kurzii Rabenhorst in Grunow to N. obtusa, Grunow also reported finer striae densities (30-32 in $10 \mu \mathrm{m})$ than Smith described (22 in $10 \mu \mathrm{m})$. Since our SEM observations of Smith's $N$. obtusa material indicate even finer striae densities ( $>40$ in $10 \mu \mathrm{m}$ ) and since we have 

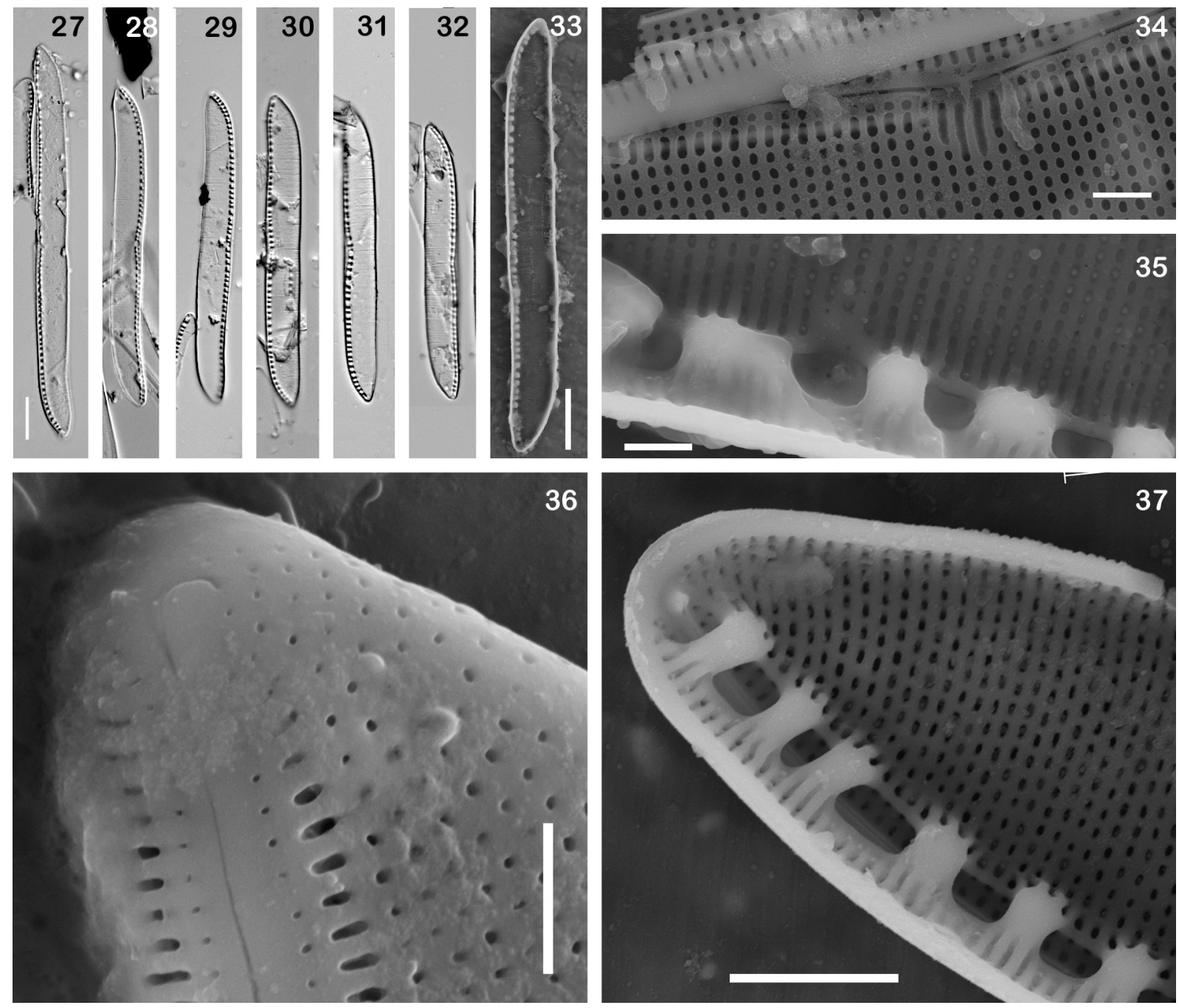

Figs 27-37. Nitzschia kurzeana Rabenhorst, LM and SEM observations on type material from Rabenhorst material \#2312 and slide GC\#35149 at the Academy of Natural Sciences, Philadelphia: (27-32) LM showing size range; (33-37) SEM: (33) entire valve, internal view. (34) valve exterior at the central part of the valve on the raphe side. Raphe is eccentric on the mantle. (35) internal view at the valve center showing raphe ends terminate at the center. Fibulae are robust. Areolae are occluded with small occlusions. (36) external view of valve apex. Distal raphe end is curved onto the valve face. (37) valve interior at apex, showing fibulae are constructed from 3-4 interstriae which are distinct at the valve. Raphe terminates in a helictoglossa. Scale bars $10 \mu \mathrm{m}(27-33), 1 \mu \mathrm{m}(34-36), 2 \mu \mathrm{m}$ (37).

not been able to review the material used by Grunow for his study, we have yet to determine if this taxon is synonymous with $N$. kurzeana, $N$. obtusa, or Nitzschia kurzii Rabenhorst ex Cleve et Möller. There is only a description associated with the name.

\section{Discussion}

North American collections of $N$. kurzeana were found in brackish sites along the coast of Florida and other Gulf of Mexico sites. Although N. obtusa is included in counts from NAWQA, the specimens we examined could be attributed to either $N$. kurzeana or N. potapo$v a e$. The reported ranges for the taxa discussed herein extend from Northern Europe and the Arctic (Grunow in Cleve \& Grunow 1880; KrassKe 1929) through the tropical and subtropical zones (RABENHORST 1873) to Egypt (this study) and into Peru (PATRICK et al. 1966) in the southern hemisphere. Although many summaries of this group indicate their presence in estuarine habitats (e.g., VAN HeurCK 1896), specimens recognized by Krasske (1929), Gasse (1986), and Krammer \& LangeBERTALOT (1988) in Europe as well as collections from this study in Egypt, are from freshwater environments suggesting these species can also occur in freshwaters. This represents great ecological breadth for such a small group of species and is another example of a group of diatoms helping to dispel the notion of a Rubicon - an ecological division of taxa based on salinity (ALVERSON et al. 2007; POTAPOVA 2011).

Taxa within this group are distinguished from one another by overall size, proportions, and valve shape (Hustedt 1930; Krammer \& LANGE-Bertalot 1988). For all of them, while there can be a significant 
size range in terms of length, the range of variation in breadth is much smaller and they all have a similar number of fibulae. Stria density also differs between some species, but was often difficult to resolve in the LM in the slides examined.

The Section Obtusae of Nitzschia is different from all other sections by a unique combination of characters that includes: sigmoid valves; eccentric raphe not in a keel elevated off of the valve face; lack of a conopeum; strongly bent, elongated external proximal raphe ends extending onto the valve face; and interruption of the raphe at the center (GRUNOW 1880; VAN HEURCK 1896; Hustedt 1930; Round et al. 1990; EHRLICH 1995; Metzeltin et al. 2005). This combination of features clearly distinguishes members of the Obtusae from Nitzschia sensu stricto, and from other 'characteristic' members of the genus (Section Lanceolatae). Phylogenetic analyses of Nitzschia and its relatives (RIMET et al. 2011; KIM et al. 2019; MANN et al. 2021) demonstrate that Nitzschia is not monophyletic, and that groups with clearly defined morphological differences are monophyletic (e.g., Simonsenia, Tryblionella, Hantzschia, Psammodictyon) in the Bacillariales. There is only one member of the Obtusae ( $N$. filiformis) listed among the 254 unique Nitzschia taxa in GenBank (accessed 24 August, 2020). In the analysis presented by Mann et al. (2021) N. filiformis is part of "Clade 6B", more akin to some members of the Lanceolatae and Nitzschiella groups than to Nitzschia sensu stricto. Inclusion of additional members of the Obtusae in future phylogenetic studies of the Bacillariales will help determine if this group of morphologically similar taxa form a monophyletic group, distinct from Nitzschia sensu stricto.

\section{ACKNOWLEDGEMENTS}

Thanks to Geraldine Reid for providing material of N. obtusa W. Smith type and Dee Breger at Drexel University for SEM assistance. SEM funding provided by the Academy of Natural Sciences to SEH. This material is based upon work supported by the U.S. Geological Survey under Cooperative Agreement \#G15AC00104. Any use of trade names is for descriptive purposes only and does not imply endorsement by the U.S. Government.

\section{REFERENCES}

Aboal, M.; Alvarez-Cobelas, M.; Cambra, J. \& Ector,
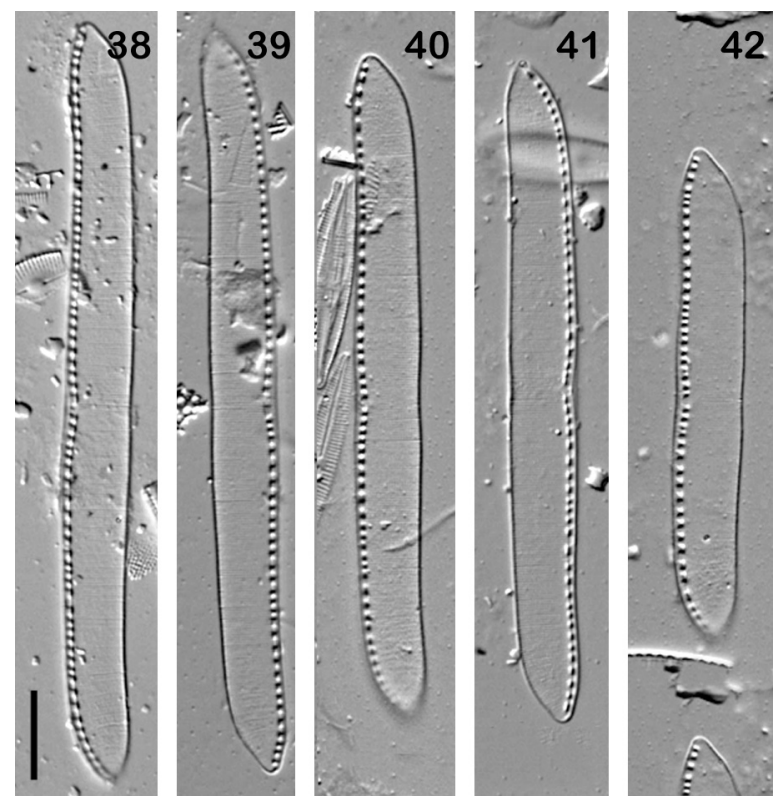

Figs 38-42. Nitzschia kurzeana, LM showing size range, observations made from slide GC103574a, Hillsboro Canal, Southern Florida, at the Academy of Natural Sciences, Philadelphia. Scale bar $10 \mu \mathrm{m}$.
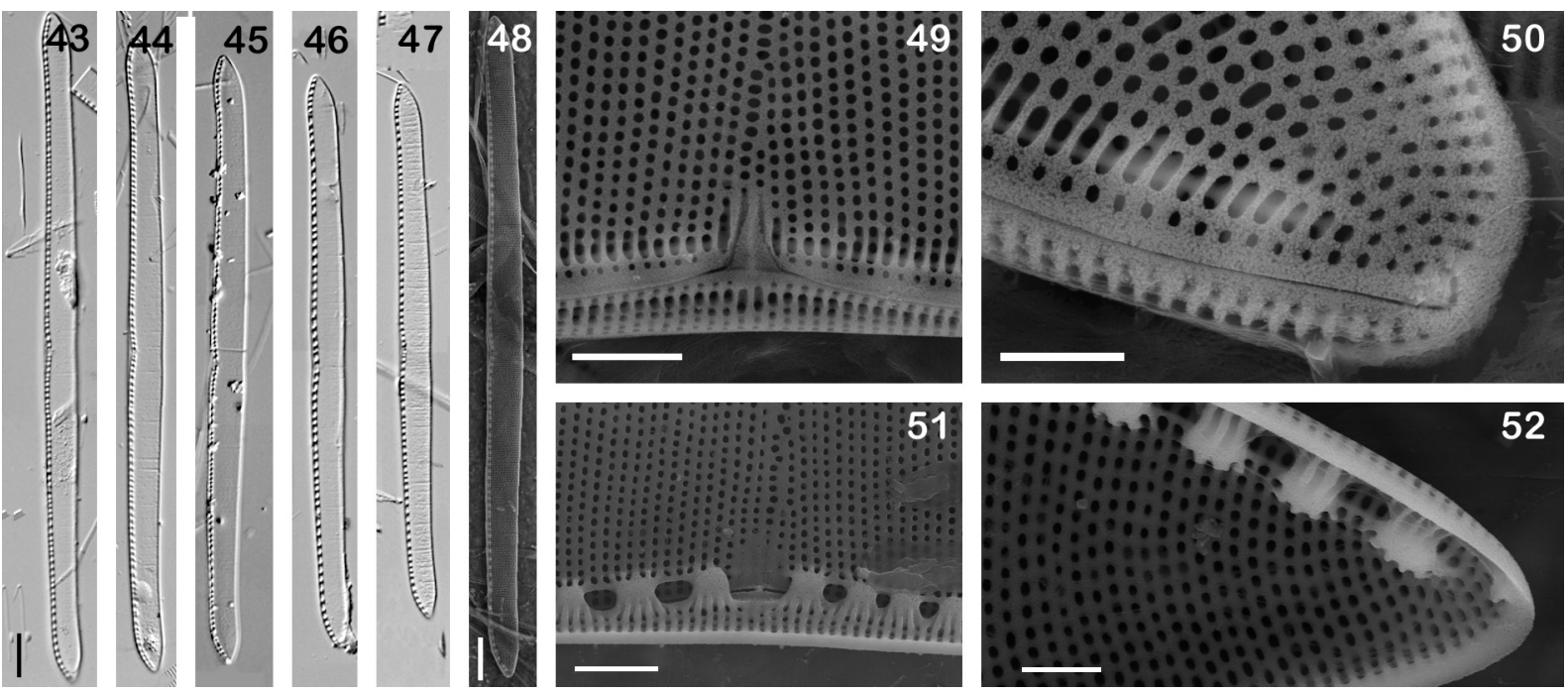

Figs 43-52. Nitzschia kurzeana, LM and SEM, observations made from slide GC 103254b, and NAWQA sample GS027353 Tamiami Canal, Florida, at the Academy of Natural Sciences, Philadelphia: (43-47) LM showing size range; (48-52) SEM: (48) entire valve, external view, (49) external view of central part of the valve showing proximal raphe ends curved onto the valve face, (50) external view of valve apex. Eccentric raphe curves tightly onto apex. (51) internal view of central nodule showing robust fibulae and small proximal raphe ends. A hyaline area extends onto the valve face from the central nodule. (52) internal view of the apex of the valve showing fibulae and small helictoglossa. Scale bars $10 \mu \mathrm{m}(43-48), 1 \mu \mathrm{m}(50,52), 2 \mu \mathrm{m}(49,51)$. 


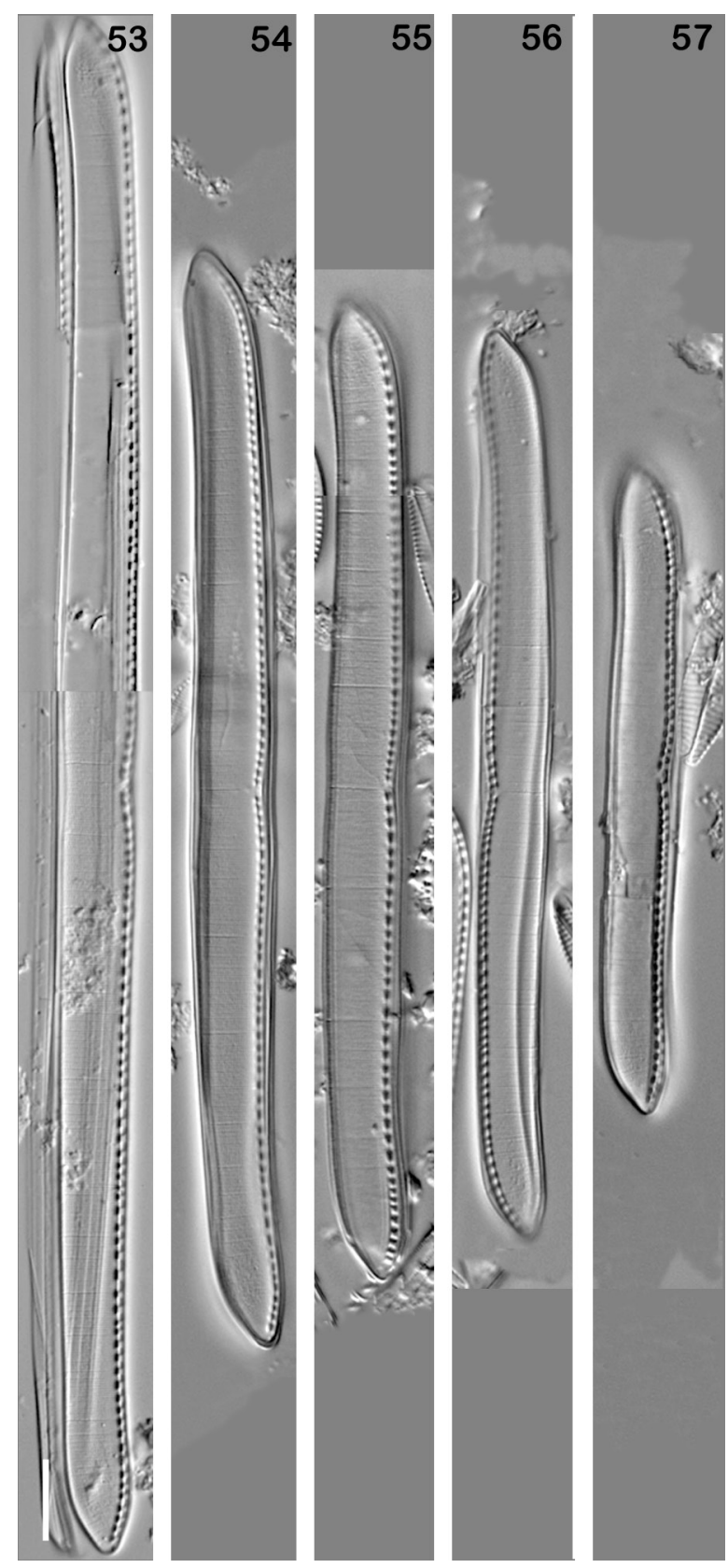

Figs 53-57. Nitzschia kurzeana, LM showing size range. Observations made from slide GC 106141a, Salado Creek, Texas, at the Academy of Natural Sciences, Philadelphia, showing size range. Scale bar $10 \mu \mathrm{m}$.

L. (2003): Floristic list of non marine diatoms (Bacillariophyceae) of Iberian Peninsula, Balearic Islands, and Canary Islands. Updated taxonomy and bibliography. - Diatom Monographs 4: 1-639.

Alverson, A.J.; JANSEn, R.K. \& Theriot, E.C. (2007): Bridging the rubicon: phylogenetic analysis reveals repeated colonizations of marine and fresh waters by thalassiosiroid diatom. - Mol. Phylogenet. Evol. 45: 193-210.

Bertolli, L.M.; Talgatti, D.M.; Nascimento, T.M.S. \& Torgan, L.C. (2019): Two new species of Tryblionella W. Smith (Bacillariaceae, Bacillariophyta) from a southern Brazil salt marsh. - Phytotaxa 399: 173-186.

Charles, D.F.; Knowles, C.A. \& Davis, R.S. (2002): Protocols for the analysis of algal samples collected as part of the U.S. Geological Survey National Water-Quality

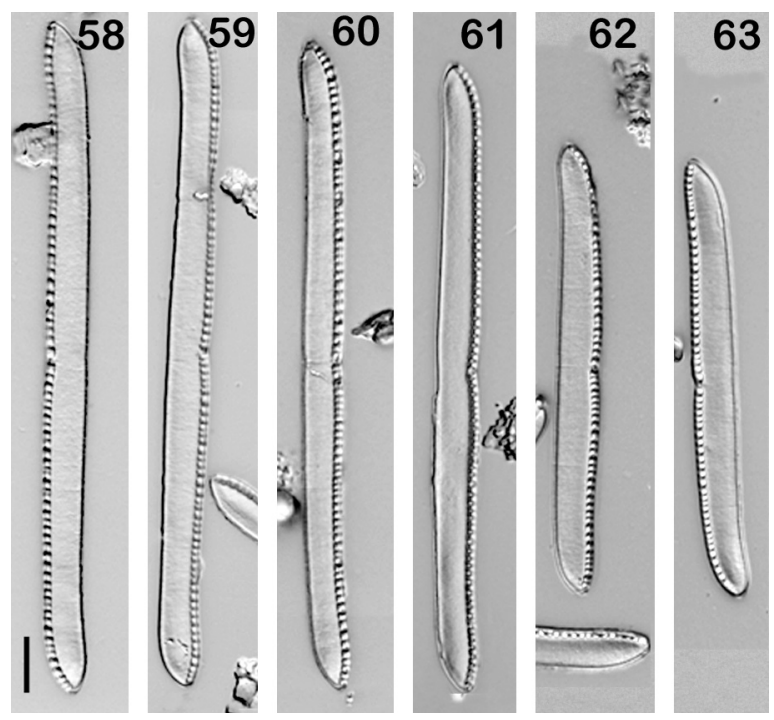

Figs 58-63. Nitzschia kurzeana, LM showing size range. Observations made from Cleve \& Möller slide \#78, at the Academy of Natural Sciences, Philadelphia. Size range shown. Scale bar $10 \mu \mathrm{m}$.

Assessment Program, Report No. 02-06. - 124 pp., Patrick Center for Environmental Research, Academy of Natural Sciences of Drexel University, Philadelphia.

Cleve, P.T. \& Grunow, A. (1880): Beiträge zur Kenntniss der Arctischen Diatomeen. - Kongliga Svenska-Vetenskaps Akademiens Handlingar 17: 1-121.

Cleve, P.T. \& Möller, J.D. (1878): Diatoms. Part 2. [Exsiccatae] 59 slides. Uppsala.

De Toni, G.B. (1892): Sylloge algarum omnium hucusque cognitarum. Vol. II. Bacillarieae. Sectio II. Pseudoraphideae. - pp. 491-817, Typis Seminarrii, Patavii.

EHRLICH, A. (1995): Atlas of the inland-water diatom flora of Israel. - In: PoR, F.D. (ed.): Flora Palaestina. - 166 pp., Geological Survey of Israel, Israel Academy of Science and Humanities, Jerusalem.

Foged, N. (1980): Diatoms in Egypt. - Nova Hedwigia 33: 629-707.

Fourtanier, E. \& Kociolek, J.P. (2011): Catalogue of Diatom Names. - California Academy of Sciences. http://research.calacademy.org/research/diatoms/ names/index.asp

Gasse, F. (1986): East African diatoms. Taxonomy, ecological distribution. - Bibliotheca Diatomologica 11: 1-201.

Grunow, A. (1880): Bemerkungen zu den Diatomeen von Finnmark, dem Karischen Meere und vom Jenissey nebst Vorarbeiten für Monographie der Gattungen Nitzschia, Achnanthes, Pleurosigma, Amphiprora, Plagiotropis, Hyalodiscus, Podosira und einiger Navicula-Gruppen. K. Sv. Vet. - Akad. Handl, Ser. 4, 17: 16-121.

HANTZSCH, C.A. (1860). Neue Bacillarien: Nitzschia vivax var. elongata, Cymatopleura nobilis. - Hedwigia 2: 1-40, pl. 6.

Hustedt, F. (1930): Bacillariophyta (Diatomeae). - In: PASCHER, A. (ed.): Die Süsswasser-Flora Mitteleuropas, Vol. 10/ 2. -466 pp., G. Fischer, Jena.

HustedT, F. (1938): Systematische und ökologische Untersuchungen über die Diatomeen-Flora von Java, Bali und Sumatra nach dem Material der Deutschen Limnologischen Sunda-Expedition. - Sonderabdruck aus dem Archiv für Hydrobiologie 15: 393-506.

Hustedt, F. (1957): Die Diatomeenflora des Flußsystems der 


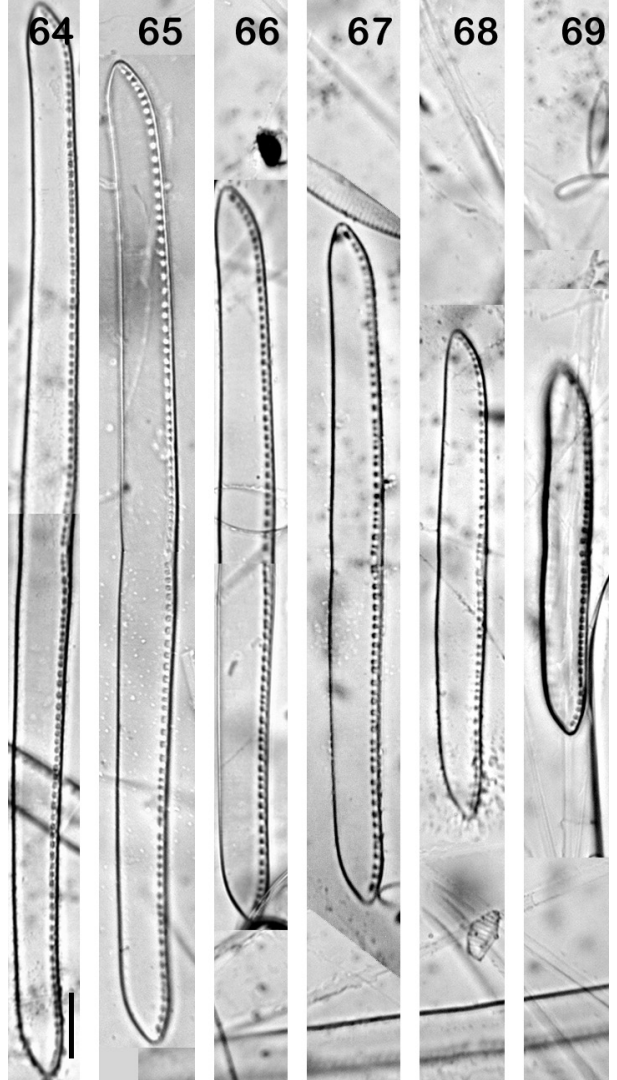

Figs 64-69. Nitzschia kurzeana, LM showing size range. Observations made from collections from Egypt with specific localities for each image provided in Table 2. Size range shown. Scale bar $10 \mu \mathrm{m}$.

Weser im Gebiet der Hansestadt Bremen. - Abhandlungen des Naturwissenschaftlichen Verein zu Bremen 34: 181-440.

HusteDT, F. (1959): Die Diatomeenflora der Unterweser von der Lesummündung bis Bremerhaven mit Berücksichtigung des Unterlaufs der Hunte und Geeste. - Veröffentlichungen des Instituts für Meeresforschung in Bremerhaven 6: $13-175$.

Index Nominum Algarum (1997-2009): University Herbarium, University of California, Berkeley. Compiled by Paul Silva. http://ucjeps.berkeley.edu/INA.html.

Kim, B.-S.; Witkowski, A.; Park, J.-G.; Li, C.; Trobajo, R.; ManN, D.G.; KIM, S.-Y.,; Ashworth, M.; BaK, M. \& GastineaU, R. (2019): Taxonomy and diversity of a little-known diatom genus Simonsenia (Bacillariaceae) in the marine littoral: novel taxa from the Yellow Sea and the Gulf of Mexico. - Plant Ecol. Evol. 152: 248-261.

KocioleK, J.P. (2004): Annotated listing of diatom types in Rabenhorst's Die Algen Europa's 1848-1882, and a consideration of their nomenclatural status. - Proceedings of the California Academy of Sciences 55: 255-299.

Kociolek, J.P.; Blanco, S.; Coste, M.; Ector, L.; Liu, Y.; KARTHICK, B.; KULIKOVSKIY, M.; LUNDHOLM, N.; Ludwig, T.; Potapova, M.; Rimet, F.; SabBe, K.; Sala, S.; SAR, E.; TAYLOR, J.; VAN DE ViJVER, B.; WetZel, C.E.; Williams, D.M.; Witkowski, A. \& WitKowski, J. (2020a): DiatomBase. http://www.diatombase.org.

KocioleK, J.P.; Danz, A.; Swenson, J.; Thirouin, K.; Williams, D.M. \& Borsa, T. (2020b): Taxonomy, valve ultrastructure, nomenclature and a comparison

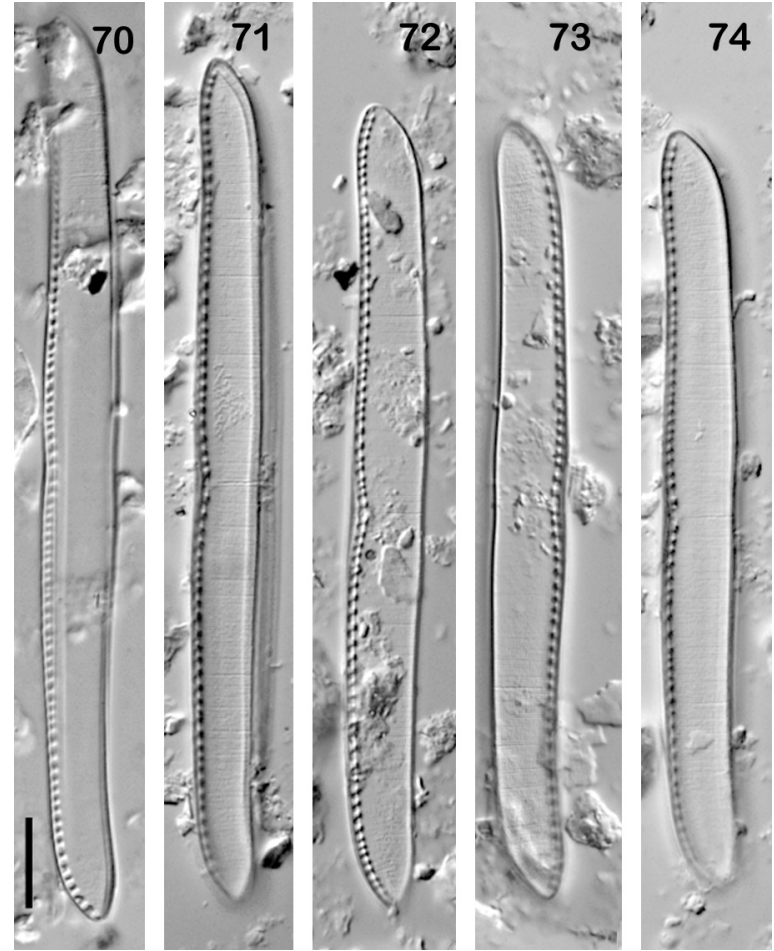

Figs 70-74. Nitzschia kurzeana var. multistriata (Hohn) comb. nov., LM showing size range. Observations made from the type slide for Nitzschia obtusa var. multistriata Hohn, GC 25861a at the Academy of Natural Sciences, Philadelphia. Size range shown. Scale bar $10 \mu \mathrm{m}$.

of two species of Bacillariales from freshwaters of Puerto Rico. - Phytotaxa 468: 190-202.

Krammer, K. \& LANGe-Bertalot, H. (1988): Süßwasserflora von Mitteleuropa. Bacillariophyceae, Teil 2/1-4. - 596 pp., Gustav Fischer Verlag, Stuttgart.

KrassKe, G. (1929): Beiträge zur Kenntnis der Diatomeenflora Sachsens. - Bot. Arch. 27: 348-380.

ManN, D.G. (1978): Studies in the Nitzschiaceae (Bacillariophyta), Vols 1 \& 2 [Ph.D. Dissertation]. - xxxiii + 386 pp. + 146 pls., University of Bristol, Bristol.

Mann, D.G.; Trobajo, R.; Sato, S.; Li, C.; Witkowksi, A.; Rimet, F.; AshWORTh, M.; Hollands, R.M. \& THERIOT, E.C. (2021): Ripe for reassessment: a synthesis of available molecular data for the speciose diatom family Bacillariaceae. - Mol. Phylogenet. Evol. 158: 106985.

Metzeltin, D.; Lange-Bertalot, H. \& García-Rodríguez, F. (2005): Diatoms of Uruguay. Compared with other taxa from South America and elsewhere. - Iconographia Diatomologica 15: 1-736.

PATricK, R.; Aldrich, F.A.; CAIRn, J. JR.; Drouet, F.; Hohn, M. H.; Roback, S.S.; SKuja, H.; SPangler, P.J.; Swabey, Y.H. \& Whitford, L.A. (1966): The Catherwood Foundation Peruvian-Amazon Expedition. - Monographs of the Academy of Natural Sciences of Philadelphia 14:1-495.

Patrick, R.M. \& Reimer, C.W. (1966): The diatoms of the United States, exclusive of Alaska and Hawaii. Vol. 1: Fragilariaceae, Eunotiaceae, Achnanthaceae, Naviculaceae. - Monographs of the Academy of Natural Sciences of Philadelphia 13: 1-688.

Peragallo, M. (1903): Le Catalogue Général des Diatomées, Vol. 2. - pp. 472-973, Clermont-Ferrand.

Petersen, J.B. (1928): The aërial Algae of Iceland. - In: 
Rosenvinge, L.K. \& WARMing, E. (ed.): The Botany of Iceland, vol. 2, part 2, no. 8. - pp. 325-447, J. Frimodt, Copenhagen - Denmark.

Potapova, M. (2011): Patterns of diatom distribution in relation to salinity. - In: SeckBACH, J. \& KocioleK, J.P. (eds): The Diatom World. - pp. 313-329, Springer, Dordrecht - The Netherlands.

RABENHORST, L. (1864): Flora Europaea Algarum aquae dulcis et submarinae. Sectio I. Algas diatomaceas complectens, cum figuris generum omnium xylographice impressis. - 359 pp., Lipsiae apud Eduardum Kummerum, Leipzig (Lipsiae).

RABENHORST, L. (1873): Index in L. Rabenhorst Algarum europaearum exiccatarum (der Algen Europa's mit Berücksichtigung des ganzen Erdballs). - Decas 232-233, Dresden.

Richter, P. (1879): Neue Bacillariaceen (Homoeocladia germanica et $H$. conferta). - Hedwigia 18: 65-67.

Rimet, F.; Kermarrec, L.; BoucheZ, A.; Hoffmann, L.; Ector, L. \& MedLIN, L. (2011): Molecular phylogeny of the family Bacillariaceae based on 18S rDNA sequences: focus on freshwater Nitzschia of the section Lanceolatae. - Diatom Res. 26: 273-291.

Round, F.E.; Crawford, R.M. \& Mann, D.G. (1990): The diatoms. Biology and morphology of the genera. -747 pp., Cambridge University Press, Cambridge.

Simonsen, R. (1960): Neue Diatomeen aus der Ostsee. II. Kieler Meeresforschungen 16: 126-160.

SмiтH, H.L. (1876-1888): Diatomacearum Species Typicae. - [Exsiccatae] 750 slides, Geneva, New York.
Sмiтh, W. (1853): Synopsis of British Diatomaceae, Vol. 1. 89 pp., pl. 1-31, John Van Voorst, London.

Turland, N. J.; Wiersema, J. H.; Barrie, F. R.; Greuter, W.; HawKsworth, D. L.; HerendeEn, P. S.; KNAPP, S.; Kusber, W.-H.; LI, D.-Z.; MARHOLD, K.; MaY, T. W.; McNeill, J.; Monro, A. M.; Prado, J.; Price, M. J. \& Sмiтh, G. F. (eds.) (2018): International Code of Nomenclature for algae, fungi, and plants (Shenzhen Code) adopted by the Nineteenth International Botanical Congress Shenzhen, China, July 2017. Regnum Vegetabile 159. - Koeltz Botanical Books, Glashütten. DOI: https://doi.org/10.12705/Code. 2018

VAn Heurck, H. (1880): Synopsis des Diatomées de Belgique. Atlas. -30 pls., Ducaju \& Cie., Anvers.

VAn Heurck, H. (1896): A treatise on the Diatomaceae. 558 pp., William Wesley \& Son, London.

VAnLANDingham, S.L. (1978): Catalogue of the fossil and recent genera and species of diatoms and their synonyms. Part VI. Neidium through Rhoicosigma. - pp. 2964-3605, J. Cramer, Vaduz.

YANG, Q.; LiU, T.; YU, P.; Zhang, J.; KocioleK, J.P.; WANG, Q. \& You, Q. (2020): A new freshwater Psammodictyon species in the Taihu Basin, Jiangsu Province, China. - Fottea 20: 144-151.

(C) Czech Phycological Society (2021)

Received December 19, 2020

Accepted May 11, 2021 